\title{
Marinobacter aquaeolei sp. nov., a halophilic bacterium isolated from a Vietnamese oil- producing well
}

\author{
Nguyen B. Huu, ${ }^{1}$ Ewald B. M. Denner, ${ }^{2}$ Dang T. C. Ha, ${ }^{1}$ Gerhard Wanner ${ }^{3}$ \\ and Helga Stan-Lotter ${ }^{4}$
}

Author for correspondence: Helga Stan-Lotter. Tel: +43662 8044 5756. Fax : +43662 8044144.
e-mail: helga.stan-lotter@ sbg.ac.at

1 Institute of Biotechnology, National Center for Natural Science and Technology, Nghia do, Tu liem, Hanoi, Vietnam

2 Institut für Mikrobiologie und Genetik, Universität Wien, Dr Bohrgasse 9, A-1030 Wien, Austria

3 Botanisches Institut der Universität München, Menzinger Str. 67, D-80638 München, Germany

4 Institut für Genetik und Allgemeine Biologie, Hellbrunnerstr. 34, A-5020 Salzburg, Austria

\begin{abstract}
Several strains of moderately halophilic and mesophilic bacteria were isolated at the head of an oil-producing well on an offshore platform in southern Vietnam. Cells were Gram-negative, non-spore-forming, rod-shaped and motile by means of a polar flagellum. Growth occurred at $\mathrm{NaCl}$ concentrations between 0 and $20 \%$; the optimum was $5 \% \mathrm{NaCl}$. One strain, which was designated VT8', could degrade n-hexadecane, pristane and some crude oil components. It grew anaerobically in the presence of nitrate on succinate, citrate or acetate, but not on glucose. Several organic acids and amino acids were utilized as sole carbon and energy sources. The major components of its cellular fatty acids were $C_{12: 0} 3-0 H, C_{16: 1} \omega 9 c, C_{16: 0}$ and $C_{18: 1} \omega 9 c$. The DNA G+C content was 55.7 mol\%. 165 rDNA sequence analysis indicated that strain VT8T was closely related to Marinobacter sp. strain CAB (99.8\% similarity) and Marinobacter hydrocarbonoclasticus (99.4\% similarity). Its antibiotic resistance, isoprenoid quinones and fatty acids were similar to those of Marinobacter hydrocarbonoclasticus and Pseudomonas nautica. However, the whole-cell protein pattern of VT8' differed from that of other halophilic marine isolates, including P. nautica. DNA-DNA hybridization indicated that the level of relatedness to Marinobacter hydrocarbonoclasticus was $65 \%$ and that to $P$. nautica was $\mathbf{7 5} \%$. Further differences were apparent in Fouriertransformed IR spectra of cells and lipopolysaccharide composition. It is proposed that $\mathrm{VTB}^{\mathrm{T}}$ should be the type strain of a new species and should be named Marinobacter aquaeolei. P. nautica may have been misclassified, as suggested previously, and may also belong to the genus Marinobacter.
\end{abstract}

Keywords: Marinobacter aquaeolei, 16S rRNA gene analysis, Fourier-transformed IR spectroscopy, lipopolysaccharide, Pseudomonas nautica

\section{INTRODUCTION}

The oil/gas fields are new and special ecosystems because of their physico-chemical and geochemical conditions. Environmental parameters such as temperature, pressure, $\mathrm{pH}$, salinity, heavy metal concentration and petroleum composition vary widely from reservoir to reservoir (Bernard et al., 1992; Bhupathiraju et al., 1993). Recently, several reports

Abbreviation: FT-IR, Fourier-transformed IR.

The EMBL accession number for the sequence reported in this paper is AJ000726. have described halophilic bacteria obtained from such environments (Adkins et al., 1993; Dang et al., 1996; Tardy-Jacquenod et al., 1996a, b). In our microbial investigation of offshore oil/gas fields near the coastal town of Vung Tau in southern Vietnam, several novel micro-organisms have been isolated, including halophilic sulfate-reducing bacteria (Dang et al., 1996). In this study, properties of a new moderately halophilic aerobic isolate (strain VT8 ${ }^{\mathrm{T}}$ ) are reported which, on the basis of genotypic and phenotypic analyses, should be placed in the recently created genus Marinobacter (Gauthier et al., 1992). Strain VT8 ${ }^{\mathrm{T}}$ shared several phenotypic properties with Marinobacter hydrocarbonoclasticus and Pseudomonas nautica, but 
differences in whole-cell protein pattern, Fouriertransformed IR (FT-IR) spectra and lipopolysaccharide (LPS) composition justified its designation as a distinct species. It has been pointed out by several authors that $P$. nautica could be clearly separated from other Pseudomonas species, i.e. that it was probably misclassified (De Ley, 1992; De Vos et al., 1989; Zumft, 1992). Our data suggest that $P$. nautica may also belong to the genus Marinobacter.

\section{METHODS}

Isolation, cultivation and maintenance of bacterial strains. Samples were collected at the head of an oil-producing well on the offshore oil/gas platform near the coastal town of Vung Tau in southern Vietnam. For enrichments and isolation, a culture medium similar to that described in American Petroleum Institute Research Publication 38 (1975) was used. It contained $\left(1^{-1}\right.$ distilled water $)$ : peptone, $10 \mathrm{~g}$; meat extract, $1 \mathrm{~g}$; glucose, $5 \mathrm{~g}$; $\mathrm{NaCl}, 100 \mathrm{~g}$; $\mathrm{MgCl}_{2} \cdot 6 \mathrm{H}_{2} \mathrm{O}, 3 \mathrm{~g}$; and phenol red, $0.018 \mathrm{~g}$. The $\mathrm{pH}$ was adjusted to 6.9-7.3 with $\mathrm{NaOH}$ before autoclaving. When necessary, agar was added at $2 \%(\mathrm{w} / \mathrm{v})$. Samples of $2 \mathrm{ml}$ each were inoculated into $12 \mathrm{ml}$ vials containing $7 \mathrm{ml}$ liquid medium. Following growth of the community by incubation at ambient temperature $\left(30-37^{\circ} \mathrm{C}\right)$, samples were transferred to agar plates by spreading. Single colonies were picked and purified further by streaking repeatedly on agar plates. Pure cultures were maintained by suspending cells in a small volume of $25 \%$ glycerol and $5 \% \mathrm{NaCl}$ in screw-capped plastic vials and keeping them frozen at $-70^{\circ} \mathrm{C}$.

Reference strains. The following strains were used for biochemical and morphological comparisons and obtained from the Deutsche Sammlung von Mikroorganismen und Zellkulturen (DSMZ): Halomonas elongata DSM 2581 ${ }^{\mathrm{T}}$, Marinobacter hydrocarbonoclasticus DSM 8798 ${ }^{\mathrm{T}}$, Marinomonas communis DSM 5604, Marinomonas vaga DSM $5605^{\mathrm{T}}$, Pseudomonas nautica DSM 50418 ${ }^{\mathrm{T}}$, Salinivibrio (formerly Vibrio) costicola DSM $11403^{\mathrm{T}}$. Sequence data from the following additional strains were used for phylogenetic comparisons (see also Fig. 4): Marinobacter sp. strain CAB, Marinobacterium georgiense ATCC $700074^{\mathrm{T}}$, Oceanospirillum japonicum ATCC 19191, Oceanospirillum commune ATCC 27118, Oceanospirillum jannaschii ATCC 27135 ${ }^{\mathrm{T}}$, Str. clone SAR92 (Sargasso Sea bacterioplankton), Str. clone agg. 53 (marine snow-associated), Chromohalobacter marismortui DSM $6770^{\mathrm{T}}$ and Piscirickettsia salmonis ATCC VR-1361.

Nutritional and growth characteristics. Marine broth 2216 (ZoBell, 1941; Difco), Halomonas complex (HMC) or defined (HMD) medium (Vreeland \& Martin, 1980; Vreeland et al., 1980) with slight modifications were used. HMC medium contained $\left(1^{-1}\right.$ distilled water): Casamino acids (Difco), $7.5 \mathrm{~g}$; peptone (Roth), $5 \mathrm{~g}$; yeast extract (Difco), $1 \mathrm{~g} ; \mathrm{NaCl}, 50 \mathrm{~g} ; \mathrm{MgSO}_{4} .7 \mathrm{H}_{2} \mathrm{O}, 20 \mathrm{~g}$; sodium citrate, $3 \mathrm{~g} ; \mathrm{K}_{2} \mathrm{HPO}_{4}, 0.5 \mathrm{~g}$; and $\mathrm{FeSO}_{4}\left(\mathrm{NH}_{4}\right)_{2} \mathrm{SO}_{4}, 0.05 \mathrm{~g}$. The $\mathrm{pH}$ was adjusted to $7 \cdot 3$ with $\mathrm{KOH}$ or $\mathrm{HCl}$ before autoclaving. HMD medium contained $\left(1^{-1}\right.$ distilled water $)$ : $\mathrm{NaCl}, \quad 50 \mathrm{~g} ; \quad \mathrm{MgCl}_{2} .6 \mathrm{H}_{2} \mathrm{O}, \quad 5.3 \mathrm{~g} ; \mathrm{KCl}, \quad 0.75 \mathrm{~g}$; $\mathrm{FeSO}_{4}\left(\mathrm{NH}_{4}\right)_{2} \mathrm{SO}_{4} .6 \mathrm{H}_{2} \mathrm{O}, \quad 0.04 \mathrm{~g} ; \quad \mathrm{K}_{2} \mathrm{HPO}_{4}, \quad 0.87 \mathrm{~g}$; $\left(\mathrm{NH}_{4}\right)_{2} \mathrm{SO}_{4}, 4 \mathrm{~g}$. When required, agar was added at $2 \%$ $(\mathrm{w} / \mathrm{v})$ concentration. Cultures in liquid media were grown in $100 \mathrm{ml}$ side-arm flasks containing $20 \mathrm{ml}$ medium. Growth was monitored by measuring $\mathrm{OD}_{600}$ in a Novaspec II instrument (Pharmacia). The temperature range for growth was between 4 and $55^{\circ} \mathrm{C}$ in $\mathrm{HMC}$ medium. The requirement for $\mathrm{NaCl}$ was determined in the same medium, which was supplemented with $0-32 \% \mathrm{NaCl}(\mathrm{w} / \mathrm{v})$. The $\mathrm{pH}$ range for growth was determined in Marine broth 2216, which was supplemented with $50 \mathrm{~g} \mathrm{NaCl}$ and whose $\mathrm{pH}$ was adjusted to 4.0-10.0 with $\mathrm{HCl}$ or $\mathrm{KOH}$. The utilization of carbohydrates as sole carbon and energy sources was tested in HMD medium (Vreeland \& Martin, 1980), which was supplemented with $5 \% \mathrm{NaCl}$ and whose $\mathrm{pH}$ was adjusted to $7 \cdot 3$ with $\mathrm{KOH}$. Carbohydrates were added at $10 \mathrm{mM}$ final concentration. The utilization of pristane $(2,6,10,14$-tetramethylpentadecane) and n-hexadecane (both from Sigma) was tested by inoculating strain $\mathrm{VT} 8^{\mathrm{T}}$ into HMD medium, which was supplemented with $1 \%(\mathrm{v} / \mathrm{v})$ of the hydrocarbon compounds. Growth was scored by measuring $\mathrm{OD}_{600}$. Degradation of crude oil fractions was tested by inoculating strain $\mathrm{VT}^{\mathrm{T}}$ into mineral medium, which contained $\left(\mathrm{I}^{-1}\right.$ tap water): $\mathrm{KNO}_{3}, 3 \mathrm{~g} ; \mathrm{NaCl}, 50 \mathrm{~g} ; \mathrm{MgSO}_{4} .7 \mathrm{H}_{2} \mathrm{O}, 0.4 \mathrm{~g}$; $\mathrm{KH}_{2} \mathrm{PO}_{4}, 0.3 \mathrm{~g} ; \mathrm{Na}_{2} \mathrm{HPO}_{4}, 0.7 \mathrm{~g}$. Crude oil $(5 \%, \mathrm{v} / \mathrm{v})$ from White tiger oil-field (Vietnam) was added and incubation proceeded for $7 \mathrm{~d}$ at $30^{\circ} \mathrm{C}$. The residual oil was analysed by GC. Control experiments were performed under identical conditions, but omitting the bacterial inoculum.

Ion specificity determination. $\mathrm{KCl}, \mathrm{LiCl}$ and $\mathrm{NH}_{4} \mathrm{Cl}$ were substituted for $\mathrm{NaCl}$ at concentrations of $0.85 \mathrm{M}$ in $\mathrm{HMC}$ medium to test for a specific ion requirement.

Phenotypic analysis. Standard tests (Gram staining, cytochrome oxidase, catalase, gelatinase) were performed as described previously (Smibert \& Krieg, 1994). The Analytical Profile Index system (API 20NE and API ZYM; bioMérieux) was used for analysis of additional enzyme activities (Humble et al., 1977) and for assimilation tests, respectively. Strips were inoculated with a bacterial suspension in minimal medium and incubated for up to 2 weeks. Antibiotic susceptibility was tested by spreading bacterial suspensions on agar plates and applying filter-paper disks (Schleicher and Schüll; $6 \mathrm{~mm}$ diameter) on which the following antibiotics were dispensed ( $\mu \mathrm{g}$ per disk shown in parentheses): ampicillin (20), anisomycin (15), bacitracin (20), chloramphenicol (30), erythromycin (15), gentamicin (30), kanamycin (30), novobiocin (30), oleandomycin (25), streptomycin (20) and tetracycline (20). Zones of inhibition were measured after $2 \mathrm{~d}$ incubation at $30^{\circ} \mathrm{C}$.

Analysis of isoprenoid quinones. Lipoquinones were extracted from lyophilized cells with methanol : hexane $(2: 1$, $\mathrm{v} / \mathrm{v}$ ) as described by Tindall (1990). The hexane phase contained the lipoquinones, which were separated by TLC on silica gel plates (Kieselgel $\mathrm{F}_{254}$; Merck), using hexane: diethylether $(85: 15, \mathrm{v} / \mathrm{v})$ as the developing solvent, and compared with lipoquinones of type strains based on $R_{F}$ values (Collins, 1994).

Electron microscopy. Cells were harvested following $1 \mathrm{~d}$ incubation in HMC medium and prepared for scanning (Denner et al., 1994) or transmission electron microscopy (Dang et al., 1996) as described previously.

Cellular fatty acid analysis. Fatty acid methyl esters were prepared and analysed by GC as described by Kuykendall et al. (1988). This work was performed by R. Kroppenstedt, DSMZ, Braunschweig, Germany.

Whole-cell protein pattern analysis. SDS-PAGE of wholecell proteins was performed as described previously (StanLotter et al., 1989). Briefly, approximately $50 \mathrm{mg}$ cells (wet 
weight) $\mathrm{ml}^{-1}$ were lysed by boiling in SDS sample buffer (Laemmli, 1970) for $10 \mathrm{~min}$, and then centrifuged at $10000 \mathrm{~g}$ for $15 \mathrm{~min}$, to remove any precipitates. The gel system of Laemmli (1970) was used. Proteins were visualized by staining with Coomassie blue. Marker proteins of 2.5$200 \mathrm{kDa}$ were from Novex. Protein gels were run at least in triplicate.

Preparation of cell envelopes and analysis of LPS. Cell envelopes were prepared by passing cells through a French press and subsequent centrifugation at $200000 \mathrm{~g}$ as described previously (Stan-Lotter \& Sanderson, 1981), except that a buffer consisting of $50 \mathrm{mM}$ Tris $/ \mathrm{HCl}, 10 \mathrm{mM} \mathrm{MgCl}_{2}$, $\mathrm{pH} \mathrm{7.4,} \mathrm{was} \mathrm{used} \mathrm{in} \mathrm{all} \mathrm{operations.} \mathrm{Cell} \mathrm{envelopes} \mathrm{were}$ suspended in SDS sample buffer (Laemmli, 1970) and 0.25\% proteinase K (Sigma) was added (Seltman et al., 1994). Following digestion at $37^{\circ} \mathrm{C}$ for $1 \mathrm{~h}$, samples were separated on the same gel system as that used for whole-cell proteins and stained with silver (Bio-Rad kit) according to the manufacturer's instructions.

FT-IR spectrometry. Bacterial strains were streaked on agar plates containing HMC medium and incubated overnight. Bacterial films were prepared by suspending one loopful ( $1 \mathrm{~mm}$ diameter) in $80 \mu \mathrm{l}$ distilled water and applying an aliquot of $35 \mu \mathrm{l}$ to a preformed sample area on a zinc selenite optical plate. Following drying of samples under reduced pressure, spectra were recorded between wave numbers 4000 and $500 \mathrm{~cm}^{-1}$ in an FT-IR spectrometer type IFS $28 / \mathrm{B}$ (Bruker) as described by Helm et al. (1991a, b). Data analysis was carried out using the opus 3.0 software for bacterial identification from the same manufacturer. At least six independent preparations of each investigated strain were measured and a mean spectrum was calculated.

DNA base composition. Cells were harvested in the late exponential phase of growth and $\mathrm{G}+\mathrm{C}$ contents were determined by the Identification Service of the DSMZ. DNA was isolated by the procedure of Visuvanathan et al. (1989) and was analysed by HPLC according to Mesbah et al. (1989) and Tamaoka \& Komagata (1984).

DNA-DNA hybridization. DNA was isolated as described by Cashion et al. (1977). Levels of DNA-DNA hybridization between isolate VT $8^{\mathrm{T}}$ and two type strains were determined spectrophotometrically by the renaturation method of De Ley et al. (1970), with modifications by Huß et al. (1983) and Escara \& Hutton (1980). Renaturation rates were computed by the program TRANSFER.BAS (Jahnke, 1992). These experiments were carried out by the Identification Service of the DSMZ.

$16 \mathrm{~S}$ rRNA sequence analysis. Sequencing of the $16 \mathrm{~S}$ rRNA gene was carried out by C. Spröer at the DSMZ (see under DNA base composition). Extraction of the genomic DNA, amplification of the 16S rDNA by PCR and purification of the products were performed as described by Rainey et al. (1996). The purified 16S rDNA was sequenced using the ABI PRISM Dye Terminator Cycle Sequencing Ready Reaction kit (Applied Biosystems) as indicated by the manufacturer. The DNA fragments of the sequencing reactions were separated and analysed using an Applied Biosystems 373 DNA Sequencer. The resulting sequences were read into the Alignment Editor ae2 (Maidak et al., 1996), aligned manually and compared with $16 \mathrm{~S}$ rRNA gene sequences of representative organisms of the gamma subclass of the Proteobacteria. Sequences which were used for comparisons were obtained from the EMBL or the RDP (Maidak et al., 1996) databases.

\section{RESULTS}

\section{Cellular and colonial morphology}

Several rod-shaped isolates were obtained from the head of an oil-producing well on the offshore oil/gas platform at Vung Tau; all were Gram-negative, formed yellowish colonies on HMC medium and exhibited a wide range of $\mathrm{NaCl}$ tolerances. Strain VT $8^{\mathrm{T}}$ was characterized further; it was a short rodshaped bacterium of $0.40 .5 \mu \mathrm{m}$ in diameter and $1.4-1.6 \mu \mathrm{m}$ in length (Fig. 1). It was characteristically found growing singly or in pairs. Cells were actively motile; transmission electron microscopy (not shown) revealed a single, frequently polar flagellum, which is also visible in some areas of Fig. 1. Spore formation was not observed under any of the growth conditions described in this work. Colonies on HMC medium containing $5 \% \mathrm{NaCl}$ were yellow, circular, convex, smooth with entire margins and $1.5-2.0 \mathrm{~mm}$ in diameter after $2 \mathrm{~d}$ cultivation at $30^{\circ} \mathrm{C}$.

\section{Cultural and biochemical characteristics}

Strain $\mathrm{VT}^{\mathrm{T}}$ grew at $0 \cdot 0-3.4 \mathrm{M} \mathrm{NaCl}$ and growth was optimal at $0.85 \mathrm{M} \mathrm{NaCl} . \mathrm{K}^{+}, \mathrm{Li}^{+}$or $\mathrm{NH}_{4}^{+}$ions were not able to replace $\mathrm{Na}^{+}$ions. The optimum growth temperature was $30^{\circ} \mathrm{C}$. The temperature range for growth was $13-50{ }^{\circ} \mathrm{C}$; no growth occurred at 55 or $4{ }^{\circ} \mathrm{C}$. The $\mathrm{pH}$ range for growth was $5-10$, with an optimum $\mathrm{pH}$ of $7 \cdot 3$. Growth was aerobic; catalase and oxidase activities were present. VT $8^{\mathrm{T}}$ could grow anaerobically with nitrate on succinate, citrate or acetate, but not on glucose. DL-Lactate, acetate, succinate, fumarate, citrate, L-glutamate and butyrate could be used as sole carbon and energy sources, but not $\mathrm{D}(-)$ arabinose, $\mathrm{D}(+)$ fructose, $\mathrm{D}(+)$ galactose, $\mathrm{D}(+)$ glucose, $\mathrm{D}(+)$ mannose, cellobiose, lactose, melibiose, sucrose, maltose, raffinose, glycerol, mannitol, sorbitol, benzoate, glycerate, oxalate, salicin, $\mathrm{N}$ acetylglucosamine or amino acids (except L-Pro, LLeu, L-Ile, L-Gln, L-Glu and L-Ala). On HMC medium,

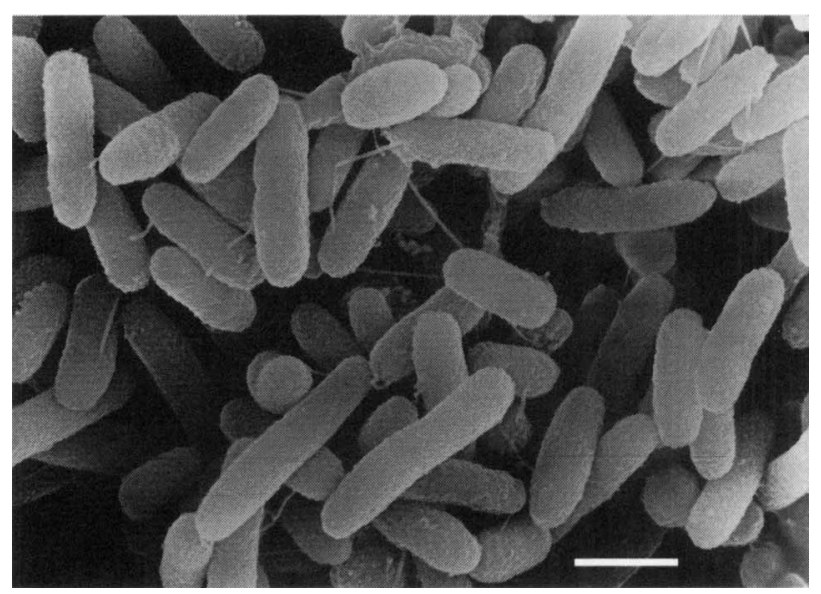

Fig. 1. Scanning electron micrograph of strain $V T 8^{\top}$ grown on Halomonas complex medium containing $5 \% \mathrm{NaCl}$. Bar, $1 \mu \mathrm{m}$. 
Table 1. Fatty acid compositions of strain $\mathrm{VT}^{\top}$, Marinobacter hydrocarbonoclasticus and P. nautica

\begin{tabular}{|c|c|c|c|}
\hline \multirow[t]{2}{*}{ Fatty acid } & \multicolumn{3}{|c|}{ Total fatty acid (\%) in: } \\
\hline & Strain $\mathrm{VTP}^{\mathrm{T}}$ & $\begin{array}{c}\text { Marinobacter } \\
\text { hydrocarbonoclasticus }\end{array}$ & $P$. nautica \\
\hline $10: 0$ & 0.57 & $1 \cdot 02$ & 0.96 \\
\hline $12: 0$ & 7.89 & $4 \cdot 66$ & $5 \cdot 88$ \\
\hline $11: 03-\mathrm{OH}$ & $0 \cdot 62$ & 0.32 & $0 \cdot 35$ \\
\hline $13: 0$ & $0 \cdot 62$ & 0.50 & 0.46 \\
\hline $12: 03-\mathrm{OH}$ & $9 \cdot 94$ & 7.74 & $9 \cdot 03$ \\
\hline 14:0 & $2 \cdot 60$ & $2 \cdot 24$ & $2 \cdot 07$ \\
\hline $15: 0$ & $2 \cdot 24$ & $1 \cdot 36$ & $1 \cdot 16$ \\
\hline $16: 0$ iso & $0 \cdot 38$ & - & - \\
\hline $16: 1 \omega 9 c$ & $11 \cdot 62$ & $7 \cdot 40$ & $8 \cdot 46$ \\
\hline $16: 1 \omega 5 c$ & $0 \cdot 46$ & 0.56 & $0 \cdot 41$ \\
\hline $16: 0$ & $22 \cdot 63$ & $23 \cdot 59$ & $25 \cdot 55$ \\
\hline 16:0 10-methyl & $2 \cdot 84$ & $2 \cdot 78$ & $6 \cdot 61$ \\
\hline $17: 1 \omega 8 c$ & $4 \cdot 54$ & $3 \cdot 60$ & $2 \cdot 79$ \\
\hline $17: 0$ & 3.78 & 3.43 & $2 \cdot 49$ \\
\hline 17:0 10-methyl & $0 \cdot 46$ & - & 0.88 \\
\hline $18: 1 \omega 9 c$ & $19 \cdot 82$ & $29 \cdot 44$ & $24 \cdot 46$ \\
\hline $18: 0$ & 1.44 & $1 \cdot 87$ & $1 \cdot 33$ \\
\hline Summed feature $4^{*}$ & 6.78 & $8 \cdot 29$ & 4.99 \\
\hline Summed feature $7^{*}$ & 0.77 & $1 \cdot 18$ & 0.81 \\
\hline
\end{tabular}

* Summed features are groups of fatty acids which were not resolved chromatographically; they consisted of fatty acids 16:1 $\omega 7 t$ and 15:0 iso 2-OH (feature 4) and isomers 18:1 $\omega 7 c, 18: 1 \omega 9 t$ and $18: 1 \omega 12 t$ (feature 7), respectively.

strain $\mathrm{VT} 8^{\mathrm{T}}$ was susceptible to the following antibiotics (diameter of inhibition zone is given in $\mathrm{mm}$ ): bacitracin (12), chloramphenicol (22), erythromycin (18), gentamicin (13), kanamycin (10) and streptomycin (9); it was resistant to ampicillin, anisomycin, novobiocin, oleandomycin and tetracycline. Antibiotic susceptibility results for Marinobacter hydrocarbonoclasticus and $P$. nautica were similar to those of strain VT8 ${ }^{\mathrm{T}}$. The following enzymes were present in strain VT ${ }^{\mathrm{T}}$ when assayed with the API ZYM system: alkaline phosphatase, esterase (C4), lipase (C8), leucine arylamidase, valine arylamidase, acid phosphatase, naphthol AS-BI phosphohydrolase and $N$-acetyl- $\beta$ glucosaminidase. These enzymes were also found in $P$. nautica. The following enzymes were not present in either strain VT $8^{\mathrm{T}}$ or $P$. nautica when assayed for with the API ZYM system: cystine arylamidase, trypsin, chymotrypsin, $\alpha$-galactosidase, $\beta$-galactosidase, $\beta$ glucuronidase, $\alpha$-glucosidase, $\alpha$-mannosidase or $\alpha$ fucosidase. The following tests were positive when assayed with the API $20 \mathrm{NE}$ system: nitrate reduction to nitrite, urease activity and gelatin liquefaction. Except for urease activity, these tests were also positive for $P$. nautica. The following tests were negative for both VT8 ${ }^{\mathrm{T}}$ and $P$. nautica when assayed for with the API 20NE system: nitrite reduction to $\mathrm{N}_{2}$, indole production, glucose oxidation, glucose fermentation, arginine dihydrolase and aesculin hydrolysis.

\section{Utilization of hydrocarbons and crude oil}

Strain VT ${ }^{\mathrm{T}}$ was able to utilize pristane, $\mathrm{n}$-hexadecane and crude oil components as sole carbon sources. Preliminary results showed that saturated hydrocarbons were reduced by $41 \%$, aromatic hydrocarbons by $52 \%$ and asphaltene by $20 \%$ over a course of $7 \mathrm{~d}$ shaking at $30^{\circ} \mathrm{C}$ in minimal medium (Dang T. C. H. \& Nguyen B. H., unpublished data).

\section{Isoprenoid quinones}

The lipoquinones of strain VT8 ${ }^{\mathrm{T}}$ were compared with lipoquinones of $P$. nautica and Marinobacter hydrocarbonoclasticus, following separation by TLC on silica gel. All three strains displayed similar levels of fluorescence quenching bands with $R_{F}$ values of about 0.3 (data not shown); this indicated the presence of ubiquinones, which are typical for many Gramnegative bacteria and are clearly distinct from menaquinones, which occur predominantly in Grampositive bacteria and archaea, and whose $R_{F}$ values are about 0.7-0.8 (Collins, 1994).

\section{Fatty acid composition}

The fatty acid compositions of VT8 ${ }^{\mathrm{T}}$ isolate and the reference strains are shown in Table 1 . The major fatty acids of strain $\mathrm{VT}^{\mathrm{T}}$ were $\mathrm{C}_{12: 0} 3-\mathrm{OH}, \mathrm{C}_{16: 1} \omega 9 c, \mathrm{C}_{16: 0}$ 


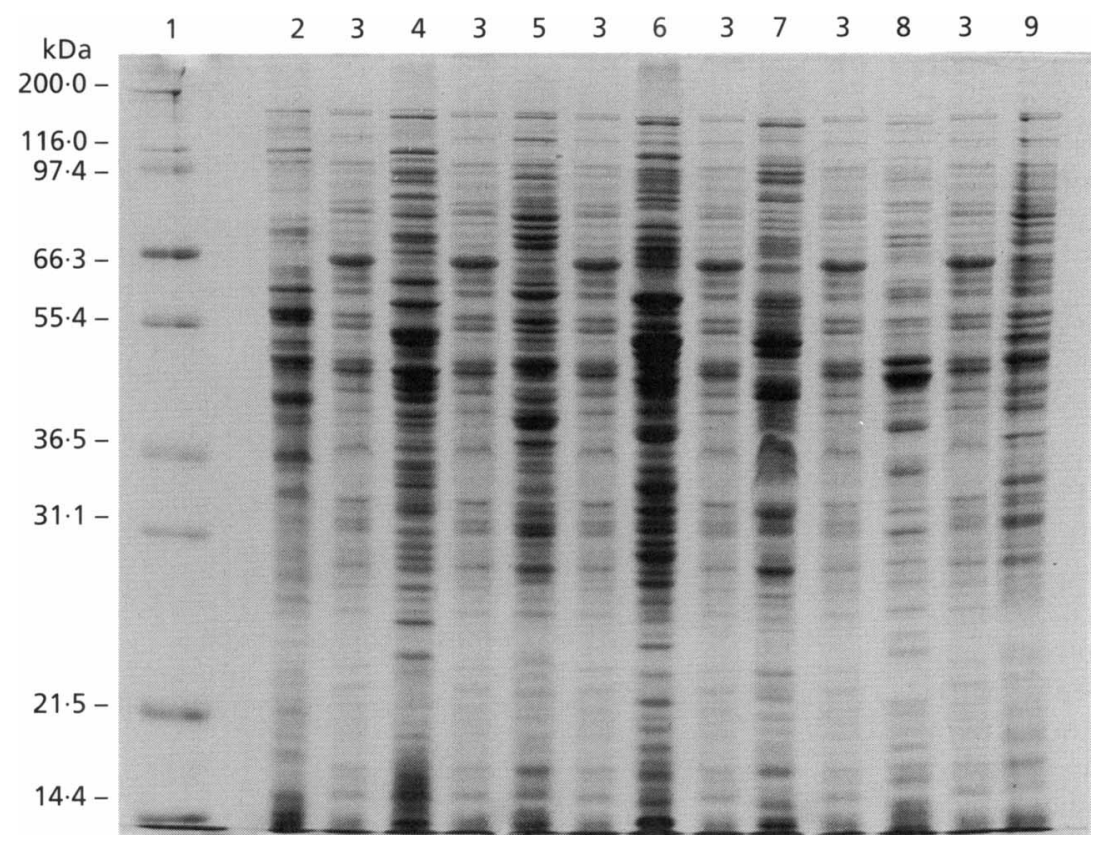

Fig. 2. Whole-cell proteins from strain $V T 8^{\top}$ and several type strains of the gamma Proteobacteria. Cells were lysed and proteins were separated by SDS-PAGE and stained with Coomassie blue (see Methods). Approximately $15-20 \mu \mathrm{g}$ protein was applied per lane. Lanes: 1, molecular mass markers; 2, H. elongata; 3, strain VT8 $; 4, C$. marismortui; 5, Marinobacter hydrocarbonoclasticus; 6, Marinomonas vaga; 7. Marinomonas communis; 8 , 5. costicola; and $9, P$. nautica.

and $\mathrm{C}_{18: 1} \omega 9 c$. The results of cellular fatty acid analysis confirmed that strain VT8 ${ }^{\mathrm{T}}$, Marinobacter hydrocarbonoclasticus and $P$. nautica had similar profiles in general, but strain VT ${ }^{\mathrm{T}}$ differed from both strains by lower levels of the fatty acids $\mathrm{C}_{16: 1} \omega 9 c$ and $\mathrm{C}_{18: 1} \omega 9 c$.

\section{Gel electrophoresis of whole-cell proteins}

SDS-PAGE of whole-cell proteins is a rapid method for distinguishing bacterial species and has a similar level of discrimination to DNA-DNA hybridization (Jackman, 1987). Bacterial cells which are grown under identical conditions produce constant protein patterns which greatly facilitate the identification of strains under investigation (Vauterin et al., 1993). This method has been widely used in the systematics of numerous bacterial strains (Kersters \& De Ley, 1980); Gram-negative bacteria with very similar protein patterns in particular exhibit unusually high DNADNA reassociation values (Vandamme et al., 1997, 1998 , and references therein). Cells of strain VT8 ${ }^{\mathrm{T}}$ were compared with several type strains of the gamma Proteobacteria with similar morphological and biochemical characteristics (Fig. 2). Strain VT $8^{\mathrm{T}}$ showed a unique protein profile which did not resemble the profiles of $H$. elongata, $C$. marismortui, Marinobacter hydrocarbonoclasticus, Marinomonas vaga, Marinomonas communis, S. costicola or P. nautica.

\section{FT-IR spectrometry}

FT-IR spectra of bacteria are recorded from whole cells, without any preparation other than drying, and provide fingerprint-like, highly reproducible patterns which can distinguish strains at the subspecies level

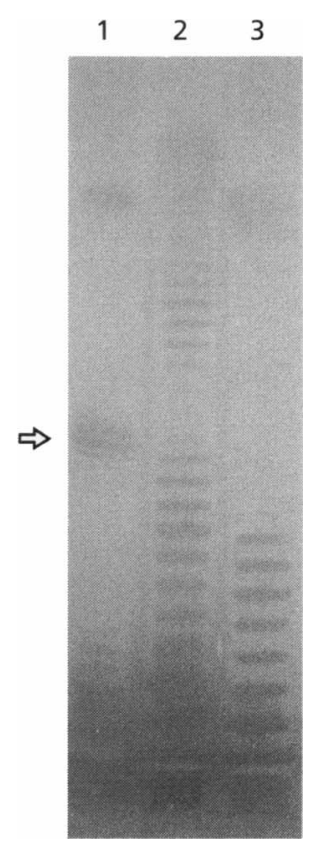

Fig. 3. Electrophoretic analysis of LPS. Following separation by SDS-PAGE, LPS was stained with silver. LPS from strain VT8 ${ }^{\top}$ (lane 1), Marinobacter hydrocarbonoclasticus (lane 2) and $P$. nautica (lane 3 ) are shown. The arrow indicates the positions of the polysaccharide chains of the LPS from strain VT ${ }^{\top}$.

(Helm et al., 1991a; Naumann et al., 1991). The spectra of strain $\mathrm{VT}^{\mathrm{T}}$ and $P$. nautica showed differences in terms of prominent additional peaks or shoulders between wave numbers 1200 and 900 (data not shown); this window represents the polysaccharide 
region (Helm et al., 1991a). Some additional differences between the two isolates were apparent between wave numbers 900 and $700 \mathrm{~cm}^{-1}$; according to Helm et al. (1991a), this region is the true fingerprint region, where remarkable spectral patterns often become apparent, although the chemical groups responsible for the spectra in this region have not yet been assigned.

\section{LPS content}

Since FT-IR spectra indicated possible differences in the polysaccharide composition of strains $\mathrm{VT} 8^{\mathrm{T}}$ and $P$. nautica, the LPS content of these strains was examined by SDS-PAGE (Fig. 3). The LPS patterns from strain $\mathrm{VT} 8^{\mathrm{T}}, P$. nautica and Marinobacter hydrocarbonoclasticus appeared as the typical series of regularly spaced bands, which represent LPS molecules with varying lengths of $O$-linked side-chains and where different distances between the bands are due to different repeating sugar units in the polysaccharide chains (Palva \& Mäkelä, 1980). While the LPS from Marinobacter hydrocarbonoclasticus and $P$. nautica (Fig. 3, lanes 2 and 3) showed a wide range of chain lengths, albeit with different spacing, that from strain VT8 $^{\mathrm{T}}$ was apparently more homogeneous (Fig. 3, arrow); in addition, the distances between bands in the LPS of strain $\mathrm{VT}^{\mathrm{T}}$ were shorter than those of the LPS from the other two strains, suggesting less sugar molecules per repeating unit. While not strictly proven, these results would be consistent with the observed differences in the polysaccharide region of the FT-IR spectra of $P$. nautica and strain $\mathrm{VT} 8^{\mathrm{T}}$.

\section{$\mathbf{G}+\mathbf{C}$ content}

The DNA $\mathrm{G}+\mathrm{C}$ content of $\mathrm{VT} 8^{\mathrm{T}}$ was $55.7 \pm 0.1 \mathrm{~mol} \%$. This value was higher than that of Marinobacter hydrocarbonoclasticus $(52.7 \mathrm{~mol} \%$; Gauthier et al., 1992) and lower than that of P. nautica (59.2\%; De Vos et al., 1989).

\section{DNA-DNA hybridization}

The measurement of DNA-DNA hybridization showed the following homology values: $65 \%$ between strain VT $8^{\mathrm{T}}$ and Marinobacter hydrocarbonoclasticus; $75.4 \%$ between strain $\mathrm{VT}^{\mathrm{T}}$ and $P$. nautica; $85.1 \%$ between Marinobacter hydrocarbonoclasticus and $P$. nautica. A DNA homology value of $65 \%$ is well below the usual criterion of approximately $70 \%$ or higher, which justifies a different species (Wayne et al., 1987). The homology values of approximately 75 and $85 \%$ between VT8 $8^{\mathrm{T}}$ and $P$. nautica, and $P$. nautica and Marinobacter hydrocarbonoclasticus, respectively, could indicate a closer relationship on the DNA level. However, the variation in several methods used for DNA-DNA hybridization is considered to range from $\pm 4-5 \%$ or higher (Balkwill et al., 1997; DSMZ Identification Service).

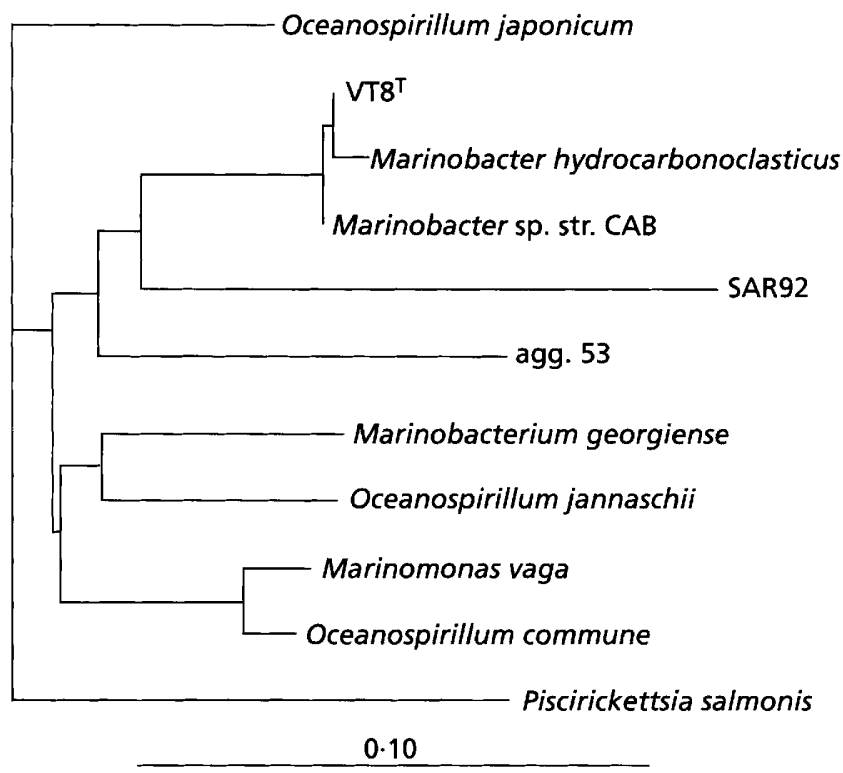

Fig. 4. Phylogenetic dendrogram indicating the position of strain $\mathrm{VT}^{\top}$ within the radiation of representatives of the gamma subclass of the Proteobacteria. The position of the root was determined by including Piscirickettsia salmonis in the analysis. The scale bar represents 10 nucleotide substitutions per 100 nucleotides.

\section{Phylogeny}

A matrix of sequence similarity of strain $\mathrm{VT} 8^{\mathrm{T}}$ and selected reference organisms from marine habitats belonging to the gamma Proteobacteria was constructed. Pairwise evolutionary distances were computed using the correction of Jukes \& Cantor (1969). From these numbers, a phylogenetic dendrogram (Fig. 4) was drawn using the neighbourjoining method (Saitou \& Nei, 1987) and the PHYLIP program (Felsenstein, 1993). Results of 16S rRNA sequence analysis suggested that strain $\mathrm{VT} 8^{\mathrm{T}}$ was more closely related to Marinobacter sp. strain CAB ( $99.8 \%$ similarity) and Marinobacter hydrocarbonoclasticus (99.4\% similarity) than to Marinobacterium georgiense (90.1\% similarity), Marinomonas vaga $(89 \cdot 2 \%$ similarity) and strains in the genus Oceanospirillum (similarity levels of $88 \cdot 8-91 \cdot 7 \%$ ). It also appeared to be closely related to $P$. nautica $(99.8 \%$ similarity; C. Spröer, unpublished data).

\section{DISCUSSION}

Strain $\mathrm{VT}^{\mathrm{T}}$ grew optimally at $0.85 \mathrm{M}(5 \%) \mathrm{NaCl}$ and could thus be classified as a moderately halophilic bacterium according to Kushner \& Kamekura (1988). It utilized a range of sugars, organic and amino acids, and other carbon sources that might be available in marine waters. The ability to grow over a range of salinities and moderate temperatures as well as to utilize a variety of substrates appear characteristic of 
numerous marine isolates. Strain $\mathrm{VT} 8^{\mathrm{T}}$ was also able to degrade hydrocarbons and some crude oil components; this was consistent with its origin from an oil-field brine. Analysis of its $16 \mathrm{~S}$ rRNA sequence placed strain $\mathrm{VT}^{\mathrm{T}}$ in the gamma subclass of the Proteobacteria, which includes, among others, the genera Oceanospirillum, Marinobacter, Marinomonas, Halomonas and Pseudomonas. The genus Marinobacter was created by Gauthier et al. (1992), and recently Rontani et al. (1997) discovered a new Marinobacter sp., strain CAB. Growth characteristics, nutritional properties and 16S rRNA sequence data suggested that VT8 ${ }^{\mathrm{T}}$ should be placed in this genus. Since the results of phylogenetic analysis indicated that strain $\mathrm{VT}^{\mathrm{T}}$ was related to Marinobacter hydrocarbonoclasticus and also to $P$. nautica (C. Spröer, unpublished data), several experiments were performed to compare strain $\mathrm{VT}^{\mathrm{T}}$ with these two species. The overall antibiotic susceptibility of strain $\mathrm{VT}^{\mathrm{T}}$ was similar to those of Marinobacter hydrocarbonoclasticus and $P$. nautica. The fatty acid composition of the three strains (Table 1) indicated a somewhat lower amount of both $\mathrm{C}_{16: 1} \omega 9 c$ and $\mathrm{C}_{18: 1} \omega 9 c$ in strain VT8 ${ }^{\mathrm{T}}$, as compared to Marinobacter hydrocarbonoclasticus and P. nautica. The $\mathrm{G}+\mathrm{C}$ contents of $P$. nautica, strain $\mathrm{VT} 8^{\mathrm{T}}$ and Marinobacter hydrocarbonoclasticus were different (59.2, 55.7 and $52.7 \%$, respectively). The DNA-DNA hybridization value of $65 \%$ between strain VT $8^{\mathrm{T}}$ and Marinobacter hydrocarbonoclasticus was below the value of approximately $70 \%$, which has been suggested for delineating a species (Wayne et al., 1987). The DNA homology values were higher between VT ${ }^{\mathrm{T}}$ and $P$. nautica $(75 \%)$ and between $P$. nautica and Marinobacter hydrocarbonoclasticus $(85 \%)$, respectively; this could partially be due to the known inherent experimental variation. Even so, high DNA-DNA hybridization values, approaching the range for species identity, should be reflected in very similar whole-cell protein patterns (Vandamme et al., 1998). The comparison of whole-cell protein patterns following separation by SDS-PAGE (Fig. 2) showed, however, that strain $\mathrm{VT}^{\mathrm{T}}$ differed markedly from other selected strains of the gamma Proteobacteria, including Marinobacter hydrocarbonoclasticus and $P$. nautica; protein patterns of the latter two were also very different. Other differences in cell constituents were apparent from the LPS patterns of the three strains. The different spacing of bands suggested not only different repeating sugar units, but also a pronounced heterogeneity of the polysaccharide chain lengths of $P$. nautica and Marinobacter hydrocarbonoclasticus (Fig. 3 ), in contrast to strain VT8 ${ }^{\mathrm{T}}$. In addition, FT-IR spectra of strain $\mathrm{VT}^{\mathrm{T}}$ and $P$. nautica showed numerous differences in the polysaccharide and 'fingerprint' regions of wave numbers (Helm et al., 1991a), which would be consistent with differences in the LPS composition. Together with the differences in the whole-cell protein patterns, these results reflect differences in the genomic content of the organism, thus suggesting that VT $8^{\mathrm{T}}$ constitutes a novel species. Taking into account the results of the phenotypic characterization and analysis of the 16S rRNA sequence, it can be concluded that strain $\mathrm{VT} 8^{\mathrm{T}}$ belongs to the genus Marinobacter.

Phylogenetic analysis placed strain VT8 ${ }^{\mathrm{T}}$ close to the recently described isolate Marinobacter sp. strain CAB (Rontani et al., 1997). This strain is not yet available for direct comparisons. However, several properties of strain CAB suggested that it differed from strain $V T 8^{\mathrm{T}}$ : optimal growth was at $0.6 \mathrm{M} \mathrm{NaCl}\left(\mathrm{VT}^{\mathrm{T}}\right.$ was $\left.0.85 \mathrm{M}\right)$; it could not grow beyond $2.5 \mathrm{M} \mathrm{NaCl}\left(\mathrm{VT}^{\mathrm{T}}\right.$ could grow up to $3.4 \mathrm{M}$ ); it could not liquefy gelatin; of the 20 amino acids tested, only Glu, Leu and Pro were utilized as carbon and energy sources (VT8 ${ }^{\mathrm{T}}$ could utilize L-Ile, L-Ala, L-Gln, in addition to L-Glu, L-Leu and L-Pro).

Marine bacteria belonging to the species $P$. nautica are Gram-negative heterotrophs; their taxonomic position remains to be established (Baumann et al., 1972; De Vos et al., 1989; Kita-Tsukamoto et al., 1993; Zumft, 1992). Kita-Tsukamoto et al. (1993) suggested that halophilic, marine pseudomonads should be separated from the genus Pseudomonas and should be placed in newly created groups. Results from the comparison of nutritional requirements, antibiotic susceptibility, isoprenoid quinones, fatty acid composition, FT-IR spectra and 16S rRNA sequence data, which were obtained during our studies with strain $\mathrm{VT}^{\mathrm{T}}$, would be consistent with a placement of $P$. nautica into the genus Marinobacter.

\section{Description of Marinobacter aquaeolei sp. nov.}

Marinobacter aquaeolei (a.quae.o'le.i. L. n. aqua water; L. n. oleum oil; M.L. gen. n. aquaeolei from water of oil, isolated from an oil-field brine).

Cells are Gram-negative, rod-shaped, non-sporeforming and motile by means of a polar flagellum. Cells are $0.4-0.5 \mu \mathrm{m}$ wide and $1.4-1.6 \mu \mathrm{m}$ long. Colonies on Halomonas complex medium are circular, yellow, convex, with entire margins; diameter is $1.5-2.0 \mathrm{~mm}$ after $2 \mathrm{~d}$ incubation at $30^{\circ} \mathrm{C}$. Growth occurs at $13-50^{\circ} \mathrm{C}$ and $\mathrm{pH} 5-10$; optimal growth occurs at $30^{\circ} \mathrm{C}$ and $\mathrm{pH} 7 \cdot 3$. The range of $\mathrm{NaCl}$ for growth is $0-20 \%$; optimal concentration is $5 \%$. Anaerobic growth occurs in the presence of nitrate on succinate, citrate or acetate, but not on glucose. DLLactate, acetate, succinate, fumarate, citrate, Lglutamate, butyrate and the amino acids L-Pro, L-Leu, L-Ile, L-Gln, L-Glu and L-Ala are utilized as sole carbon and energy sources. n-Hexadecane, pristane and some crude oil components are degraded. Susceptible to chloramphenicol, erythromycin, streptomycin, kanamycin, gentamicin and bacitracin; not susceptible to tetracycline, novobiocin, oleandomycin, anisomycin or ampicillin. The DNA G $+\mathrm{C}$ content is $55 \cdot 7 \pm 0 \cdot 1 \mathrm{~mol} \%$ (as determined by HPLC). The type strain is VT8 ${ }^{\mathrm{T}}$, which was isolated from an oilproducing well on an offshore platform in southern Vietnam. It has been deposited in the Deutsche 
Nguyen B. H. and others

Sammlung von Mikroorganismen und Zellkulturen as DSM $11845^{\mathrm{T}}$ and in the American Type Culture Collection as ATCC $700491^{\mathrm{T}}$.

\section{ACKNOWLEDGEMENTS}

We thank Drs R. Kroppenstedt and C. Spröer, both at DSMZ Braunschweig, for the analysis of the fatty acids and $16 S$ rRNA sequences and the determination of the $G+C$ content, respectively. The excellent technical assistance of $S$. Dobler is gratefully acknowledged. This work was supported by a fellowship from the Austrian Academic Exchange Service (ÖAD Nord-Süd-Dialog Stipendienprogramm) to N.B.H. D.T.C.H. and N.B.H. thank the Vietsovpetro Company and their colleagues at the Department of Petroleum Microbiology for help with the collection of samples. E. B. M.D. acknowledges Dr F. Mertens (Bruker) for supplying the IFS/28B instrument and for technical support. N.B.H. thanks Claudia Gruber and Christian Radax for help with the experimental work.

\section{REFERENCES}

Adkins, J. P., Madigan, M. T., Mandelco, L., Woese, C. R. \& Tanner, R. S. (1993). Arhodomonas aquaeolei gen. nov., sp. nov., an aerobic, halophilic bacterium isolated from a subterranean brine. Int J Syst Bacteriol 43, 514-520.

American Petroleum Institute Research Publication 38 (1975). Recommended Practice for Biological Analysis of Subsurface Injection Waters, 3rd edn, pp. 1-7. Dallas, TX: American Petroleum Institute.

Balkwill, D. L., Drake, G. R., Reeves, R. H. \& 7 other authors (1997). Taxonomic study of aromatic-degrading bacteria from deep-terrestrial-subsurface sediments and description of Sphingomonas aromaticivorans sp. nov., Sphingomonas subterranea sp. nov. and Sphingomonas stygia sp. nov. Int J Syst Bacteriol 47, 191-201.

Baumann, L., Baumann, P., Mandel, M. \& Allen, R. D. (1972). Taxonomy of aerobic marine eubacteria. $J$ Bacteriol 110, 402-429.

Bernard, F. P., Connan, J. \& Magot, M. (1992). Indigenous microorganisms in connate water of many oil fields: a new tool in exploration and production techniques. In 67th Annual Technical Conference and Exhibition of Society of Petroleum Engineers, Washington, DC, pp. 467-476. Richardson, TX: Society of Petroleum Engineers.

Bhupathiraju, V. K., Mclnerney, M. J. \& Knapp, R. M. (1993). Pretest studies for a microbially enhanced oil recovery field pilot in a hypersaline oil reservoir. Geomicrobiol J 11, 19-34.

Cashion, P., Hodler-Franklin, M. A., McCully, J. \& Franklin, M. (1977). A rapid method for base ratio determination of bacterial DNA. Anal Biochem 81, 461-466.

Collins, M. D. (1994). Isoprenoid quinones. In Chemical Methods in Prokaryotic Systematics, pp. 265-309. Edited by $M$. Goodfellow \& A. G. O'Donnell. Chichester: Wiley.

Dang, P. N., Dang, T. C. H., Lai, T. H. \& Stan-Lotter, H. (1996). Desulfovibrio vietnamensis sp. nov., a halophilic sulfate-reducing bacterium from Vietnamese oil fields. Anaerobe 2,

De Ley, J. (1992). The Proteobacteria: ribosomal RNA cistron similarities and bacterial taxonomy. In The Prokaryotes. A Handbook on the Biology of Bacteria: Ecophysiology, Isolation, Identification, Applications, vol. 2, 2nd edn, pp. 2111-2140.
Edited by A. Balows, H. G. Trüper, M. Dworkin, W. Harder \& K.-H. Schleifer. New York: Springer.

De Ley, J., Cattoir, H. \& Reynaerts, A. (1970). The quantitative measurement of DNA hybridisation from renaturation rates. Eur J Biochem 12, 133-142.

Denner, E. B. M., McGenity, T. J., Busse, H.-J., Wanner, G., Grant, W. D. \& Stan-Lotter, H. (1994). Halococcus salifodinae sp. nov., an archaeal isolate from an Austrian salt mine. Int $J$ Syst Bacteriol 44, 774-780.

De Vos, P., Van Landshoot, A., Segers, P. \& 9 other authors (1989). Genotypic relationships and taxonomic location of unclassified Pseudomonas and Pseudomonas-like strains by deoxyribonucleic acid: ribosomal ribonucleic acid hybridizations. Int $J$ Syst Bacteriol 39, 35-49.

Escara, J. F. \& Hutton, J. R. (1980). Thermal stability and renaturation of DNA in dimethylsulphoxide solutions: acceleration of renaturation rate. Biopolymers 19, 1315-1327.

Felsenstein, J. (1993). PHYLIP (Phylogeny Inference Package), version 3.5.1. Department of Genetics, University of Washington, Seattle, WA, USA.

Gauthier, M. J., Lafay, B., Christen, R., Fernandez, L., Acquaviva, M., Bonin, P. \& Bertrand, J.-C. (1992). Marinobacter hydrocarbonoclasticus gen. nov., sp. nov., a new, extremely halotolerant, hydrocarbon-degrading marine bacterium. Int J Syst Bacteriol 42, 568-576.

Helm, D., Labischinski, H., Schallehn, G. \& Naumann, D. (1991a). Classification and identification of bacteria by Fourier-transform infrared spectroscopy. J Gen Microbiol 137, 69-79.

Helm, D., Labischinski, H. \& Naumann, D. (1991b). Elaboration of a procedure for identification of bacteria using Fouriertransform IR spectral libraries: a stepwise correlation approach. J Microbiol Methods 14, 127-142.

Humble, M. W., King, A. \& Philips, I. (1977). API ZYM, a simple rapid system for the detection of bacterial enzymes. $J$ Clin Pathol 30, 275-277.

Huß, V. A. R., Festl, H. \& Schleifer, K. H. (1983). Studies on the spectrometric determination of DNA hybridisation from renaturation rates. Syst Appl Microbiol 4, 184-192.

Jackman, P. J. H. (1987). Microbial systematics based on electrophoretic whole-cell protein patterns. In Methods in Microbiology, vol. 19, Current Methods for Classification and Identification of Microorganisms, pp. 209-225. Edited by R. R. Colwell \& R. Grigova. London: Academic Press.

Jahnke, K.-D. (1992). BASIC computer program for evaluation of spectroscopic DNA renaturation data from GILFORD Syst 2600 spectrometer on a PC/XT/AT type personal computer. $J$ Microbiol Methods 15, 61-73.

Jukes, T. H. \& Cantor, C. R. (1969). Evolution of protein molecules. In Mammalian Protein Metabolism, vol. 3, pp. 21-132. Edited by H. N. Munro. New York: Academic Press.

Kersters, K. \& De Ley, J. (1980). Classification and identification of bacteria by electrophoresis of their proteins. In Microbiological Classification and Identification, pp. 273-297. Edited by M. Goodfellow \& R. G. Board. New York: Academic Press.

Kita-Tsukamoto, K., Oyaizu, H., Nanba, K. \& Simidu, U. (1993). Phylogenetic relationship of marine bacteria, mainly members of the family Vibrionaceae, determined on the basis of $16 \mathrm{~S}$ rRNA sequences. Int $J$ Syst Bacteriol 43, 8-19.

Kushner, D. J. \& Kamekura, M. (1988). Physiology of halophilic eubacteria. In Halophilic Bacteria, vol. I, pp. 109-140. Edited by F. Rodriguez-Valera. Boca Raton, FL: CRC Press.

Kuykendall, L. D., Roy, M. A., O'Neill, J. J. \& Devine, T. E. (1988). 
Fatty acids, antibiotic resistance, and deoxyribonucleic acid homology groups of Bradyrhizobium japonicum. Int J Syst Bacteriol 38, 358-361.

Laemmli, U. K. (1970). Cleavage of structural proteins during the assembly of the head of the bacteriophage T4. Nature 227, 684-685.

Maidak, B. L., Olsen, G. J., Larsen, N., McCaughey, M. J. \& Woese, C. R. (1996). The ribosomal database project (RDP). Nucleic Acids Res 24, 82-85.

Mesbah, M., Premachandran, U. \& Whitman, W. B. (1989). Precise measurement of the $\mathrm{G}+\mathrm{C}$ content of deoxyribonucleic acid by high-performance liquid chromatography. Int J Syst Bacteriol 39, 159-167.

Naumann, D., Helm, D. \& Labischinski, H. (1991). Microbiological characterizations by FT-IR spectroscopy. Nature 351, 81-82.

Palva, E. T. \& Mäkelä, P. H. (1980). Lipopolysaccharide heterogeneity in Salmonella typhimurium analyzed by sodium dodecyl sulfate polyacrylamide gel electrophoresis. Eur $J$ Biochem 107, 137-143.

Rainey, F. A., Ward-Rainey, N., Kroppenstedt, R. M. \& Stackebrandt, E. (1996). The genus Nocardiopsis represents a phylogenetically coherent taxon and a distinct actinomycete lineage: proposal of Nocardiopsaceae fam. nov. Int J Syst Bacteriol 46, 1088-1092.

Rontani, J.-F., Gilewicz, M. J., Michotey, V. D., Zheng, T. L., Bonin, P. C. \& Bertrand, J.-C. (1997). Aerobic and anaerobic metabolism of 6,10,14-trimethylpentadecan-2-one by a denitrifying bacterium isolated from marine sediments. Appl Environ Microbiol 63, 636-643.

Saitou, N. \& Nei, M. (1987). The neighbor-joining method: a new method for reconstructing phylogenetic trees. Mol Biol Evol 4, 406-425.

Seltmann, G., Voigt, W. \& Beer, W. (1994). Application of physico-chemical typing methods for the epidemiological analysis of Salmonella enteritidis strains of phage type 25/17. Epidemiol Infect 113, 411-424.

Smibert, R. M. \& Krieg, N. R. (1994). Phenotypic characterization. In Manual of Methods for General Microbiology, pp. 607-654. Edited by P. Gerhardt, R. G. E. Murray, W. A. Wood \& N. R. Krieg. Washington, DC: American Society for Microbiology.

Stan-Lotter, H. \& Sanderson, K. E. (1981). Interactions of cations with membrane fractions of smooth and rough strains of Salmonella typhimurium and other Gram-negative bacteria. $J$ Bacteriol 146, 542-551.

Stan-Lotter, H., Lang, F. J., Jr \& Hochstein, L. I. (1989). Electrophoresis and isoelectric focusing of whole cell and membrane proteins from the extremely halophilic archaebacteria. Appl Theor Electrophor 1, 147-153.

Tamaoka, J. \& Komagata, K. (1984). Determination of DNA base composition by reversed-phase high-performance liquid chromatography. FEMS Microbiol Lett 25, 125-128.

Tardy-Jacquenod, C., Magot, M., Laigret, F., Kaghad, M., Patel, B. K. C., Guezennec, J., Matheron, R. \& Caumette, P. (1996a). Desulfovibrio gabonensis sp. nov., a new moderately halophilic sulfate-reducing bacterium isolated from an oil pipeline. Int $J$ Syst Bacteriol 46, 710-715.

Tardy-Jacquenod, C., Caumette, P., Matheron, R., Lanau, C., Arnauld, O. \& Magot, M. (1996b). Characterization of sulfatereducing bacteria isolated from oil-field waters. Can J Microbiol 42, 259-266.

Tindall, B. J. (1990). Lipid composition of Halobacterium lacusprofundi. FEMS Microbiol Lett 66, 199-202.

Vandamme, P., Devriese, L. A., Pot, B., Kersters, K. \& Melin, P. (1997). Streptococcus difficile is a nonhemolytic group B, type Ib streptococcus. Int J Syst Bacteriol 47, 81-85.

Vandamme, P., Torck, U., Falsen, E., Pot, B., Goossens, H. \& Kersters, K. (1998). Whole-cell protein electrophoretic analysis of viridans streptococci: evidence for heterogeneity among Streptococcus mitis biovars. Int J Syst Bacteriol 48, 117-125.

Vauterin, L., Swings, J. \& Kersters, K. (1993). Protein selectrophoresis and classification. In Handbook of New Bacterial Systematics, pp. 251-280. Edited by M. Goodfellow \& A. G. O'Donnell. London: Academic Press.

Visuvanathan, S., Moss, V. S., Stanford, J. L., Hermon-Taylor, J. \& McFadden, J. J. (1989). Simple enzymatic method for isolation of DNA from diverse bacteria. J Microbiol Methods 10, 59-64.

Vreeland, R. H. \& Martin, E. L. (1980). Growth characteristics, effects of temperature, and ion specificity of the halotolerant bacterium Halomonas elongata. Can J Microbiol 26, 746-752.

Vreeland, R. H., Litchfield, C. D., Martin, E. L. \& Elliot, E. (1980). Halomonas elongata, a new genus and species of extremely salttolerant bacteria. Int $J$ Syst Bacteriol 30, 485-495.

Wayne, L. G., Brenner, D. J., Colwell, R. R. \& 9 other authors (1987). International Committee on Systematic Bacteriology. Report of the ad hoc committee on reconciliation of approaches to bacterial systematics. Int J Syst Bacteriol 37, 463-464.

ZoBell, C. E. (1941). Studies on marine bacteria. I. The cultural requirements of heterotrophic aerobes. J Mar Res 4, 42-75.

Zumft, W. G. (1992). The denitrifying prokaryotes. In The Prokaryotes. A Handbook on the Biology of Bacteria: Ecophysiology, Isolation, Identification, Applications, vol. 1, 2nd edn, pp. 554-582. Edited by A. Balows, H. G. Trüper, M. Dworkin, W. Harder \& K.-H. Schleifer. New York: Springer. 